\title{
Design of Program Objective Structure in Marine Ecotourism Development
}

\author{
Muksin* \\ Agribusiness Departement \\ Politeknik Negeri Jember, Indonesia \\ Jember, Indonesia \\ muksin@polije.ac.id \\ Bustang \\ Directorate of state apparatus \\ National Development Planning \\ Agency, Jakarta, Indonesia \\ Jakarta, Indonesia
}

\author{
S L Sakdiyah \\ Agribusiness Departement \\ Politeknik Negeri Jember, Indonesia \\ Jember, Indonesia
}

D Purwoko

Center for Society and Culture

Research

Indonesian Institute of Sciences

Jakarta, Indonesia

\author{
R Iskandar \\ Agribusiness Departement \\ Politeknik Negeri Jember, Indonesia \\ Jember, Indonesia
}

Eni Karsiningsih

Agribusiness Departement

Universitas Bangka Belitung, Indonesia

Bangka Belitung, Indonesia

\begin{abstract}
Ecotourism has become one of the tourist's favourites. Bangsring Underwater (Bunder) tourism is marine ecotourism in Banyuwangi East Java, that has increased tourist visits. Bunder's management involves the local community. Community engagement is expected to have a significant impact on the better management of natural resources. However, the implementation of ecotourism management from various elements other than society encounters some difficulties, especially in balancing between the objectives of improving people's quality of life, the pressure of tourism activities in the marine environment, or the utilization of wisely maintained resources. This research aims to design the objective structure of the program and determine what factors are the key to the development of marine ecotourism. The research method uses library studies and expert assessments to assess the subelements of the program's objectives, and the next stage uses Interpretive Structural Modeling analysis to design structures and determine critical factors for marine ecotourism development. The results of the research analysis found there are four levels of goal structure, and the vital elements in the development of marine ecotourism are improving people's quality of life, improving service services, realizing sustainable resource utilization, realizing maritime tourism management arrangements, expanding employment, and increasing people's income. The balance of objectives for sustainable coastal resources, tourism business performance, and community wellbeing is important to the common consciousness.
\end{abstract}

Keywords-Program Objective Structure, Marine Ecotourism, Development, and Interpretive Structural Modeling

\section{INTRODUCTION}

Marine tourism is a form of tourism that has great potential in contributing to the development of an area. If the mention marine tourism then actually what is meant by marine tourism is very broad. Marine tourism consists of swimming, diving, enjoying the beauty of the beach and the sea, holding fish and eating it, other activities that can be done on the beach and the ocean [1]. Marine tourism is a form of ecotourism that facilitates the introduction of the community to coastal resources and efforts to increase their benefits for community welfare. Marine tourism is also vital for the dynamics of the economic movement of the community, considering that Indonesia has one of the most extended stretches of abstinence in the world. This long stretch of coast has also provided the fact that many people depend on their economy from coastal and oceanic activities.

BUNDER marine tourism (Bangsring Underwater) is marine tourism located on the beach of Bangsring, Banyuwangi Regency. Banyuwangi Regency has a variety of natural landscapes, starting from the plateau in the form of mountainous areas, lowlands and coastlines that stretch along $175.8 \mathrm{~km}$. The long coastline has provided its advantages for Banyuwangi district which is located at the eastern tip of East Java province. Bunder is one of the natural attractions or ecotourism that offers beauty, snorkeling and diving activities, coral reef management, and efforts to maintain the sustainability of natural resources that involve the communities around the coast and the oceans. The Banyuwangi district government has carried out efforts to empower communities around Bangsring beach in managing marine tourism as well as conservation.

Bunder is a marine tourism destination that grows from public awareness to manage damaged coastal areas and coral reefs. The damage was caused by the exploitation of fishing by the surrounding community who ignored the concept of conservation. Damage to natural resources results in a decrease in the number of fish and catch biota obtained by the community. The decline in the quality of these resources has become a turning point for some community groups to implement conservation consciously. The conservation, which is carried out simply, turns out to provide recovery power in the coastal area. The improvement in the quality of coastal and marine resources has increased the interest of outsiders to visit. Continuous efforts in conservation should be of concern to all parties whether from government, business or entrepreneurs, communities and environmental groups [1]. Conservation takes a long way to achieve it. Most importantly, the balance in conservation activities must be lightened by improving the economic aspects and social quality of society [2]. 
During its development, Bangsring Beach, Banyuwangi Regency has become one of the marine tourism destinations with increasing visits from tourists. As a whole, Banyuwangi regency itself, since 2016-2019, has seen significant visits reaching five million domestic tourists and hundreds of thousands of foreign tourists. Of these, some visits to Bunder have jumped sharply in the last five years. In general there is an increase in interest and visits to beach tourism [3].

Increased visits to Bangsring and Bunder beaches have put pressure on the quality of these coastal ecosystems. This pressure occurs in the form of exploitation of coastal and surrounding resources to facilitate visits. Pressure also raises problems and obstacles in the management and use of natural resources. Exploitation on a large scale has the potential to destroy coastal ecosystems which will and eventually become environmental damage. Some destinations for exploiting beaches and oceans often conflict with conservation goals [4].

The existence of an integrated development effort through the right strategy is needed to develop Bangsring beach towards sustainable ecotourism. Based on these considerations, this study aims to design a structural model for the development program objectives and determine the critical factors of Bangsring beach development that provide economical and sustainable benefits.

\section{METHODS}

The research approach used in this research is explanatory research. The research seeks to explain the phenomena that occur and identify elements that are important for further structuring as a model that helps more systematic follow-up efforts.

Elements and sub-elements or factors that have the potential to influence ecotourism development are determined based on the literature review. Furthermore, these elements and factors are filtered based on their influence on ecotourism development by expert judgment using geometric or geomean averages. In the next stage, the elements and factors that have been obtained are tested again to be assessed by experts to determine the extent of their influence on the development of the Bangsring coastal marine ecotourism system. The experts in question are the Banyuwangi Regency Tourism Office, the local village head, researchers, academics who are capable of scientific judgment in developing coastal ecotourism, and a group of leaders who manage the Bangsring Underwater Marine Tourism.

The data obtained were then analyzed using the Interpretative Structural Modeling (ISM) method to identify and conclude the relationship between specific variable factors, which describe a problem or issue in coastal ecotourism development. Systematically, the stages of ISM analysis include element identification, contextual relationships, preparation of Structural Self-Interaction Matrix (SSIM), preparation of the Reachability Matrix (RM), Canonical Matrix, and Digraph (Directional Graph). Overall ISM provides a prominent picture of the elements or factors of the system and the flow of their relationship to form an appropriate decision-making framework.

\section{RESUlTS AND DISCUSSION}

Based on the assessment of experts, the elements of program objectives are essential elements in the development of Bangsring coastal ecotourism. The sub-elements or factors for ecotourism development are the components for which coastal ecotourism development is carried out. The factors of the objectives of the Bangsring Underwater marine tourism management program shown in Table 1.

TABle 1. Sub Element or FACTOR of PROGRAM OBJECTIVES

\begin{tabular}{cl}
$\begin{array}{c}\text { Element } \\
\text { Code }\end{array}$ & \multicolumn{1}{c}{ Sub Element } \\
\hline E1 & Increase the diversification of tourism service products \\
E2 & Improve the quality of life of the community \\
E3 & Improve marine tourism services \\
E4 & Achieve sustainable resource utilization \\
E5 & Realizing the development of marine tourism \\
E6 & Expanding employment \\
E7 & Increase regional economic activity \\
E8 & Increase interest in tourism investors \\
E9 & Increase local income \\
E10 & Increase community income \\
\hline
\end{tabular}

In the objective element, there are ten objectives of the Bunder marine tourism development program. The objective factors of the ecotourism development program, when viewed based on table 1, refer to economic factors, the quality of life of the community, and the ecosystem and its sustainability. These three factors are critical and become the estuary of all development goals. These three factors reflect the balance of community health both economically, socially and sustainably as well as the sustainability of the carrying capacity of natural resources.

Furthermore, the comparison between factors was carried out through SSIM. Based on SSIM analysis, the next stage of $\mathrm{RM}$ formulation. RM shows the level of influence (driver power) and the level of dependence (dependence) of an element. The results of the analysis using the Reachability Matrix (RM) show that increasing the diversification of tourism service products (E1) and improving the quality of life of the community (E2) are the objectives of the Bunder marine tourism development program which has the highest influence (driver power), this indicates that if the program objectives achieved, then the other goals will become easy to achieve. Diversification of tourism service products is essential to serve as the main objective of designing development programs. This is intended so that tourists can easily access the Bangsring Underwater (Bunder) marine tourism. Also, the aim of the development program must also be aimed at improving the quality of life of the community so that conflicts do not occur between tourists, managers, government, and the community in the future.

The objective of the Bunder marine tourism development program which has almost no influence (driver power) is to increase the interest of tourism investors (E8), this can occur because the interest of investors to invest in the tourism sector will automatically increase if the environment and conditions of the community around the place conducive travel so that this goal is a goal that will be achieved automatically if other purposes such as the diversification of tourism service products and the quality of life of the community have been implemented and improved. 
The results of the RM analysis obtained by the Canonical Matrix are intended to classify elements at the same level. The canonical matrix on the Bangsring Underwater (Bunder) Marine Tourism in Banyuwangi Regency is shown in Figure 1.

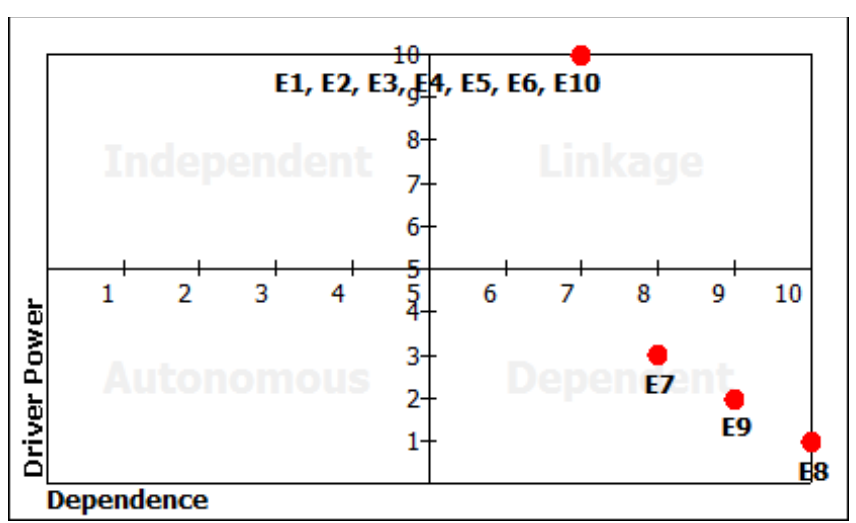

Fig. 1. Canonical Matrix of Program Objective Elements

Based on the Canonical Matrix analysis, it can be seen that increasing the diversification of tourism service products (E1), improving the quality of life of the community (E2), improving marine tourism services (E3), realizing sustainable resource use (E4), realizing the development of marinetourism (E5), expanding employment (E6), and increasing community income (E10) are the objectives of the development program in the linkage quadrant, this shows that the program objectives in that quadrant are interrelated and influence each other in achieving Bunder tourism development and are able to affect the sub-elements above it.

In addition to the sub-elements in the linkage quadrant, increasing regional economic activity (E7), increasing interest in tourism investors (E8), and rising local income (E9) are sub elements that are in the dependent quadrant, this means that the program objectives in this quadrant easily influenced by other elements.

Digraph is intended to show a graph of directly related elements and hierarchical levels. The following is a digraph matrix analysis on the Bangsring Underwater (Bunder) Marine Tourism in Banyuwangi Regency in Figure 2.

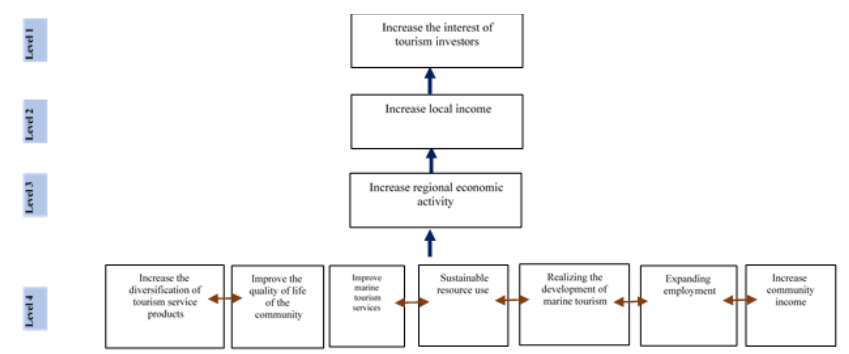

Fig. 2. Program Objective
Based on the results of the Digraph, it shows that there are four levels in the objective structure of the Bunder marine tourism development program in Banyuwangi Regency. Level 4 is a level that can influence level 3, level 2, and level 1 . At level 4, namely, the factors increasing the diversification of tourism service products (E1), improving the quality of life of the community (E2), improving marine tourism services (E3), realizing sustainable resource utilization (E4), realizing the development of nautical tourism (E5), expanding employment (E6), and increasing community income (E10). At level 4, these are the goals that should receive priority in the development of ecotourism. The handling of these objectives will have an influence and dynamism on efforts to increase regional economic activity (E7), increase local income (E9), as well as efforts to improve the interest of tourism investors (E8).

\section{CONCLUSION}

Priority objectives in the development of Bunder beach ecotourism include development aimed at increasing diversification of tourism service products, improving the quality of life of the community, improving marine tourism services, realizing sustainable resource utilization, realizing the development of marine tourism, expanding employment opportunities, and increasing community income. These priority objectives emphasize the aspects of managing human resources, sustainable coastal resources, and improving the performance of the tourism business to improve community welfare.

\section{ACKNOWLEDGMENT}

We express our gratitude to Banyuwangi District Tourism Office, Bangsring Bunder Beach Ecotourism Managers, Bangsring Coastal Area Communities and its surroundings who have facilitated the study. Thanks are also conveyed to the Jember State Polytechnic which has given support to this study. We hope that this study contribute to the development of ecotourism and particularly that of Banyuwangi area.

\section{REFERENCES}

[1] I. Mafruhah, S. Supriyono, N. S. Mulyani, and N. Istiqomah, "Causality between tourism industry development and the ecological sustainability in marine environment: A convergence and divergence among stakeholder with mactor analysis," Int. J. Energy Econ. Policy, vol. 10, no. 4, pp. 85-92, 2020, doi: 10.32479/ijeep.7989.

[2] J. DeLorenzo and E. J. Techera, "Ensuring good governance of marine wildlife tourism: a case study of ray-based tourism at Hamelin Bay, Western Australia," Asia Pacific J. Tour. Res., vol. 24, no. 2, pp. 121135, 2019, doi: 10.1080/10941665.2018.1541186.

[3] D. Jang, W. Cho, and K. Lee, "A Study on the development strategy for marine leisure tourism: Using the Importance Performance Analysis (IPA) method," Sport Mont, vol. 18, no. 1, pp. 39-45, 2020, doi: $10.26773 /$ smj.200207.

[4] K. R. M. Suiseeya, "Contesting Justice in Global Forest Governance The Promises and Pitfalls of REDD+," Conserv. Soc., vol. 15, no. 2, pp. 189-200, 2017, doi: 10.4103/cs.cs. 